\title{
Ultrastructure of cyst-like fungal bodies in myxomycete fruiting bodies
}

\author{
YUKA YAJIMA, SHIGEKI INABA, YOSUKE DEGAWA, \\ TAMOTSU HOSHINO and NORIO KONDO
}

\begin{abstract}
YAJIMA, Y., INABA, S., DEGAWA Y., HOSHINO, T. \& KONDO, N. 2013: Ultrastructure of cyst-like fungal bodies in myxomycete fruiting bodies. - Karstenia 53: 00-00. HELSINKI. ISSN 0453-3402.

This is the first report on ultrastructural observations of nivicolous myxomycete fruiting
bodies with cyst-like bodies. One specimen had immature fruiting bodies of a Lampro-
derma sp. just after spore cleavage. Using light microscopy and scanning and trans-
mission electron microscopy, countless cyst-like bodies were observed inside of the
developing spores, capillitium, columella and stalk. A second specimen consisted of
mature fruiting bodies of $L$. echinosporum. Outward appearance of the fruiting bodies
was normal with numerous cyst-like bodies inside the entire fruiting body. The cyst-like
bodies in both myxomycete specimens have a common morphology: 5-6 $\mu$ m in diam,
being transparent under light microscopy and densely warted by SEM and TEM obser-
vation. The partial sequence of the $18 \mathrm{~S}$ rDNA gene of the first specimen suggested that
cyst-like bodies were in the Cryptomycota (including Rozellida), placed at the root of
a fungal clade.
\end{abstract}

Key words: Nivicolous Lamproderma, plasmodial slime molds, Rozella, SEM, Stemonitaceae, TEM, arctic-alpine mycology

Yuka Yajima \& Tamotsu Hoshino, National Institute of Advanced Industrial Science and Technology (AIST), Sapporo 062-8517,JAPAN; e-mails: yuka44@frontier.hokudai. ac.jp; tamotsu.hoshino@aist.go.jp

Shigeki Inaba, Biological Resource Center (NBRC), National Institute of Technology and Evaluation (NITE), Kisarazu, 292-0818,JAPAN; e-mail: inaba-shigeki@nite.go.jp

Yosuke Degawa, Sugadaira Mountain Research Center, University of Tsukuba, Ueda, 386-2204, JAPAN; e-mail: degawa@sugadaira.tsukuba.ac.jp

Norio Kondo, Gradate School of Agriculture, Hokkaido University, Sapporo 060-8589, JAPAN; e-mail:norikon@res.agr.hokudai.ac.jp

\section{Introduction}

Myxomycetes (plasmodial slime molds) are eukaryotic microorganisms commonly found on decaying leaf litter or logs in forests. Under natural conditions, myxomycetes are often found feeding on bacteria (Keller et al. 1973). Microorganisms that include yeasts, mold spores, protozoans, and algae also serve as food sources for the myxomycete plasmodium (Keller \& Braun
1999, Keller et al. 2008). Here we present ultrastructural observations of nivicolous myxomycetes (snowbank slime molds) with fungal cyst-like bodies. Nivicolous myxomycetes are an ecological group of species found growing as plasmodia and fruiting bodies under melting snow during springtime. Little is known about their life cycle due to the difficulty of spore to spore culture in the laboratory (Lado 2004). We also discuss the effects of the cyst-like body on the fructification 
of nivicolous myxomycetes. This article is part of the proceedings of the $9^{\text {th }}$ International Symposium of Arctic and Alpine Mycology (ISAM) held at Kevo Subarctic Research Station in Inari Lapland, Finland, 26.08. - 01.09.2012.

\section{Material and methods}

Specimen (SAPA 100012) was collected in Hagigaoka, Ebetsu-shi, Hokkaido, Japan, at the edge of melting snow, 16 April 2005 by the first author, on fallen coniferous leaves and leaves of living herbaceous plants. Fruiting bodies were found just outside the melting snow edge, as immature white fruiting bodies. The second specimen (TNS-M-H 7200) was obtained on loan from the Department of Botany, National Museum of Nature and Science, Tokyo, Japan (TNS). The specimen was collected in Tambara, Gunma Prefecture, Japan, 2 May 1995 on a fallen deciduous leaf, and the collector is unknown. The first author identified this specimen as Lamproderma echinosporum Meyl. due to spore ornamentation, although this specimen is recorded as L. maculatum Kowalski in TNS. For observations with the light microscope (LM), mature fruiting bodies were removed from the substratum and embedded in Hoyer's medium. Dried fruiting bodies were coated with gold palladium and observed with SEM (JSM-5310LV). For observation of surface structures of spores and cyst-like bodies, they were coated with gold palladium and viewed by SEM following the protocol of Moreno et al. (2006). Myxomycete spores and cyst-like bodies were rehydrated in concentrated aqueous ammonia solution (28\%) for 20 min, dehydrated in $70 \%$ ethanol for $30 \mathrm{~min}$, fixed for $2 \mathrm{~h}$ in $100 \%$ ethylene glycol dimethyl ether, immersed in $100 \%$ acetone for $2 \mathrm{~h}$ and finally immersed in $100 \%$ isoamyl acetate for at least $1 \mathrm{~h}$, followed by critical point drying and sputter coating with gold-palladium. For sectioning, the immature and mature sporophores were removed from the substratum and fixed with $4 \%$ glutaraldehyde in $50 \mathrm{mM}$ phosphate buffer. These materials were washed in phosphate buffer, post-fixed with osmium tetraoxide, dehydrated with ethanol, and embedded in Quetol 651. Sections for light microscopy were $1 \mu \mathrm{m}$ thick and unstained. Transmission Electron Microscope (TEM) sections of $70 \mathrm{~nm}$, were stained with uranyl acetate and lead.

For phylogenic analysis, fifty invading cyst-like bodies were separated from the specimen (SAPA100012) under the light microscope. These fungal cyst-like bodies and the myxomycete sporothecae (SAPA 10012) including fungal cyst-like bodies were disrupted in a micro-test tube with a plastic pestle in $100 \mu$ of sterile distilled water. The homogenate was used as the template for the polymerase chain reaction (PCR). The $18 \mathrm{~S}$ rDNA was amplified with the primer pairs 18-F (5'-ATCTGGTTGATCCTGCCAGT-3') and 18-R (5'-GATCCTTCCGCAGGTTCACC-3'), as described by Ueda-Nishimura \& Mikata (1999). PCR product was purified using a QIAquick PCR Purification Kit (Qiagen) and sequenced on an ABI PRISM 3100 Genetic Analyzer (Applied
Biosystems, Foster City, CA, USA) using the primers, 18-F, NS2 (5'-GGCTGCTGGCACCAGTCATGC-3'), NS3 (5'-GCAAGTCTGGTGCCAGCAGCC-3'), NS4 (5'-CTTCCGTCAATTCCTTTAAG-3'), NS5 (5'-AACTTAAAGGAATTGACGGAAG-3'), NS6 (5'-GCATCACAGACCTGTTATTGCCTC-3'), NS7 (5'-GAGGCAATAACAGGTCTGTGATGC-3') (White et al. 1990) and 18-R. Multiple alignments of the 18S rDNA sequences were performed, and the nucleotide substitution rate was calculated. A phylogenetic tree was constructed by the neighbour-joining method (Kimura 1980, Saitou \& Nei 1987) using the program CLUSTAL W (Thompson et al. 1994) with bootstrap values based on 1000 replications (Felsenstein 1985).

\section{Results}

The immature fruiting bodies of Lamproderma $\mathrm{sp}$ (SAPA 10012) are shown in Fig. 1a. Thick cross sections of the immature sporotheca showed brown capillitial threads and numerous cystlike bodies. The cyst-like body was 5-6 $\mu \mathrm{m}$ in diam, transparent and almost smooth under light microscopy and sometimes found inside of the capillitial threads (Fig. 1b). The cyst-like bodies were found in incipient myxomycete spores under TEM (Fig. 1c, e). There was an electron-light zone between the cyst-like body and the myxomycete cytoplasm (Fig. 1d). The outer cyst wall was seen as a thin electron dense wavy layer. The inner cyst wall layer was much thicker than the outer layer, seen as an electron light zone. The internal cyst-like body cytoplasm contained lipid bodies. The cyst-like bodies were found inside and outside of the myxomycete stalk (Fig. 1f).

Specimen (TNS-M-H 7200) was represented by mature fruiting bodies of Lamproderma echinosporum. Outward (Fig. 2a) and inward (Fig. 3a) morphology of the fruiting bodies, and spores (Fig. 4h) were normal. The cyst-like bodies were observed inside of the sporothecae as white grains when the peridium ruptured (Fig. 2b). We could not observe any cyst-like bodies and hyphae on the substratum. Under the light microscope, there were countless cyst-like bodies that invaded the entire fruiting body of the myxomycete, i.e., hypothallus (Fig. 3c), outside of stalk (Fig. 3b), columella, capillitium (Figs. 3d, f), peridium (Fig. 3g) and spores (Figs. 3ik). Cyst-like bodies were also observed inside a horizontal section of the stalk, TEM (Fig. 5d). Under SEM, the cyst-like bodies were completely covered with myxomycete materials when in the capillitium and peridium (Figs. 4c, d). Free 

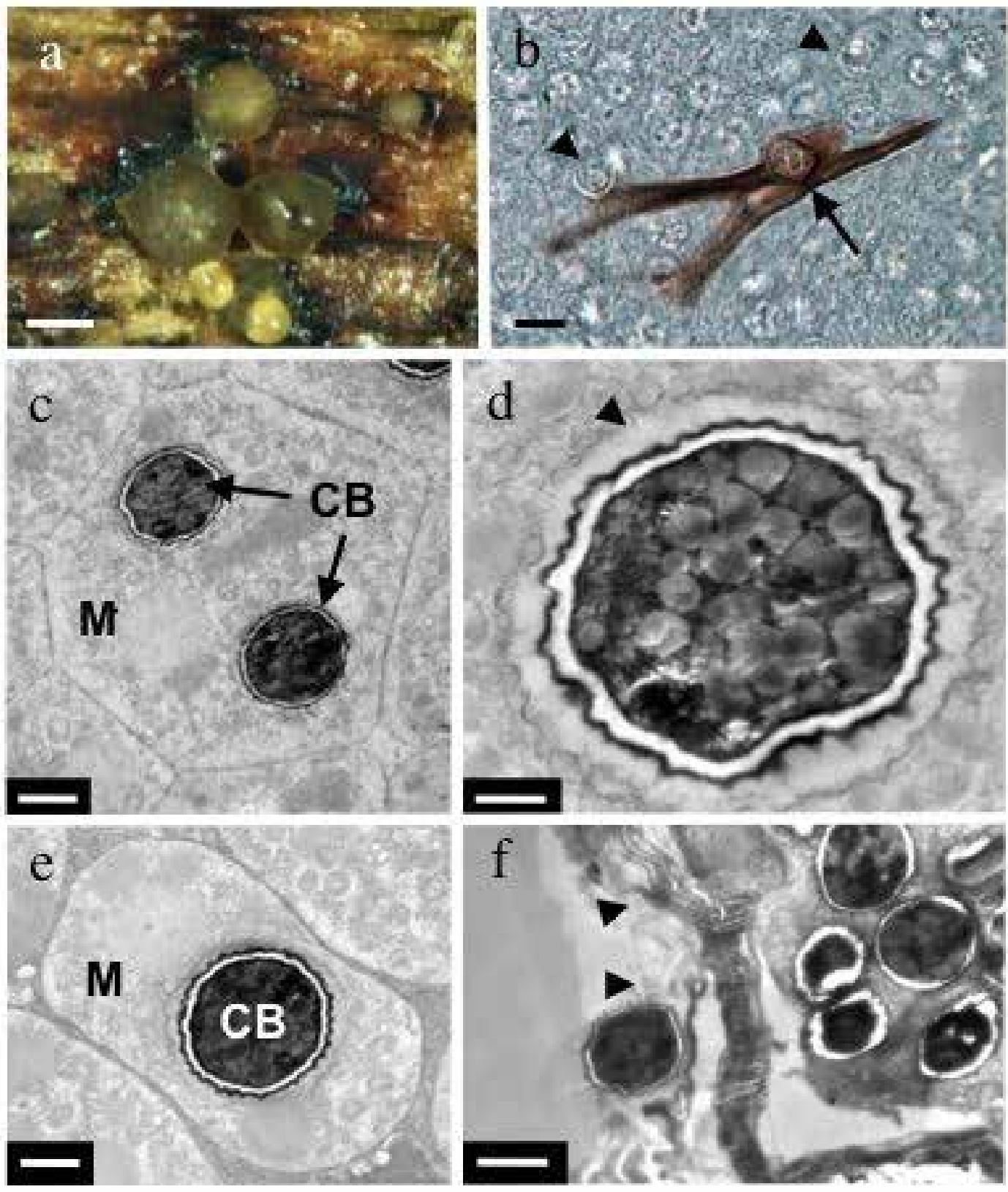

Fig. 1. Stereo, light and transmission electron micrographs of immature sporophores of Lamproderma sp. (SAPA 100012). $\mathrm{a}=$ six sporophores under a stereo microscope, $\mathrm{b}=\mathrm{a}$ horizontal thick section of sporotheca under a light microscope; numerous clear bodies (arrowheads) were observed in the sporotheca and the inside of the capillitium (arrow), $\mathrm{c}=$ an incipient myxomycete spore $(\mathrm{M})$ with two cyst-like bodies $(\mathrm{CB}), \mathrm{d}=\mathrm{a}$ cyst-like body with an electron-light zone surrounding it (arrowed), $\mathrm{e}=$ an incipient myxomycete spore $(\mathrm{M})$ with a cyst-like body $(\mathrm{CB}), \mathrm{f}=$ part of horizontal section of a stalk (ST) with cyst-like bodies inside and outside the stalk; bacteria were observed in the slime sheath (arrowhead). Scales: $\mathrm{a}=1 \mathrm{~mm}, \mathrm{~b}=5 \mu \mathrm{m}, \mathrm{c}, \mathrm{f}=3 \mu \mathrm{m}, \mathrm{d}, \mathrm{e}=2 \mu \mathrm{m}$. Photos: Y. Yajima 

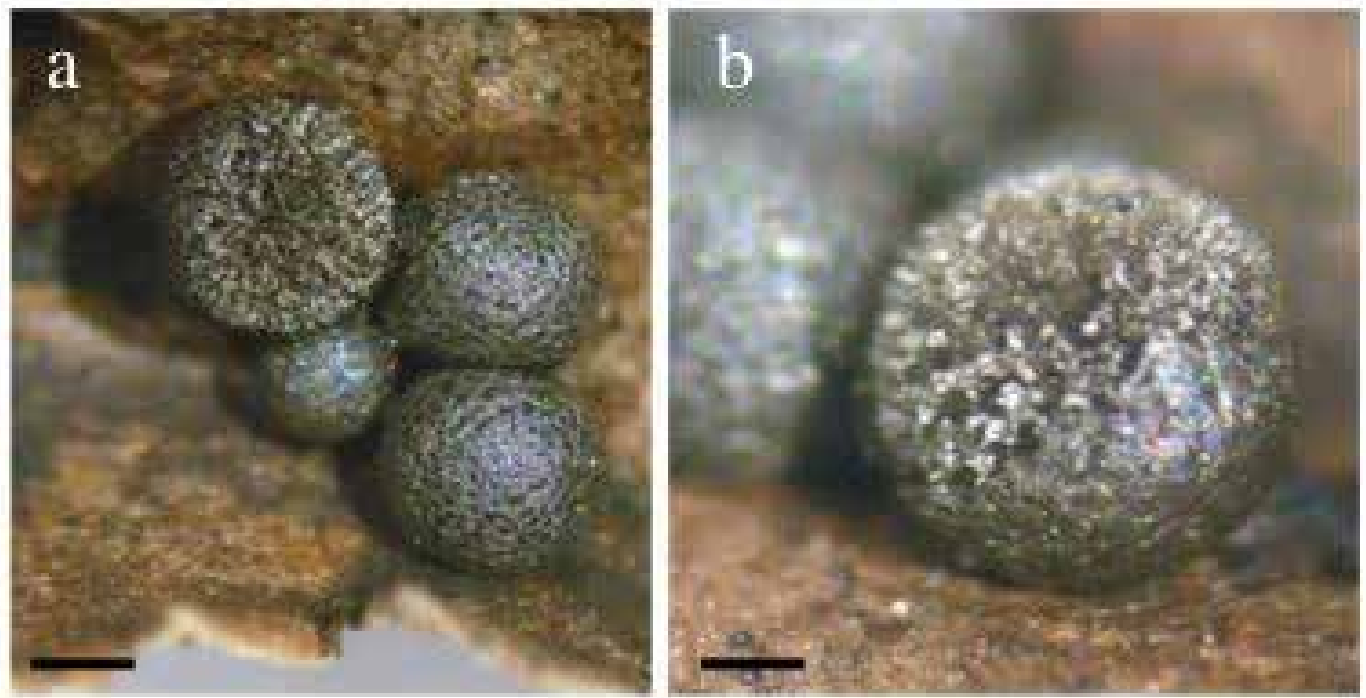

Fig. 2. Sporophores of Lamproderma echinosporum (TNS-M-H 7200). $\mathrm{a}=$ four sporocarps, $\mathrm{b}=$ detail of a sporocarp showing many white grains (cyst-like bodies) inside the sporophore. Scales: $a=1 \mathrm{~mm}, \mathrm{~b}=0.2 \mathrm{~mm}$. Photos: Y. Yajima

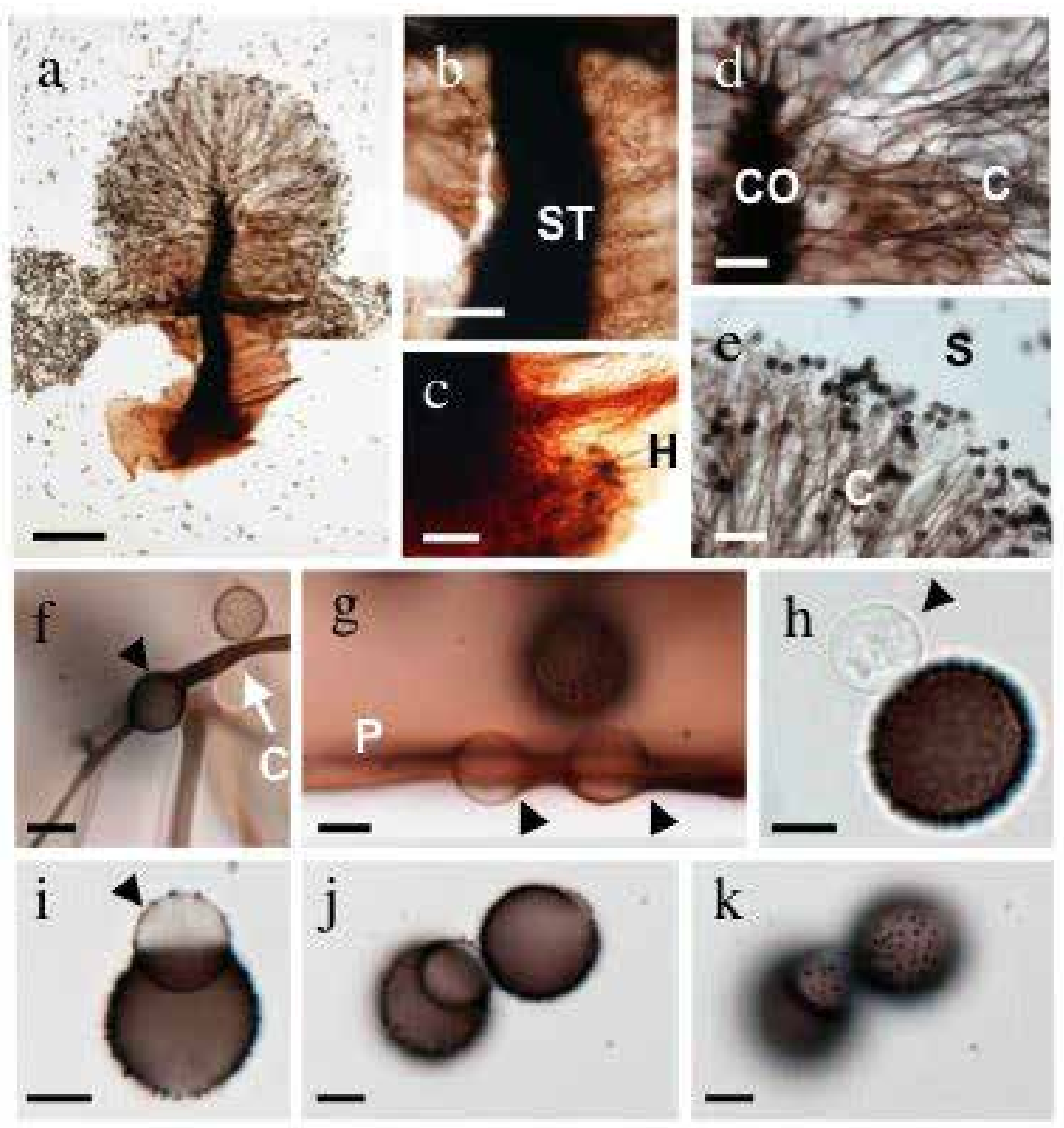

Fig. 3. Light micrographs of Lamproderma echinosporum (TNS-M-H 7200) with cyst-like bodies. $\mathrm{a}=$ sporophore, $\mathrm{b}=\operatorname{stalk}(\mathrm{ST})$ with cyst-like bodies outside, $\mathrm{c}=$ the bottom part of a stalk and hypothallus $(\mathrm{H})$ with transparent cyst-like bodies in the hypothallus, $\mathrm{d}=$ columella and capillitium, $\mathrm{e}=$ tip of a capillitium, $\mathrm{f}=$ a capillitial thread with two cystlike bodies, $g=$ part of a peridium with a spore and two cyst-like bodies, h, i $=$ spores with a cyst-like body, j, k = two spores with a cyst-like body. Scales: $\mathrm{a}=0.3 \mu \mathrm{m}, \mathrm{b}, \mathrm{d}$, e $=100 \mu \mathrm{m}, \mathrm{c}=60 \mu \mathrm{m}, \mathrm{f}-\mathrm{k}$ $=5 \mu \mathrm{m}$. Photos: Y. Yajima 

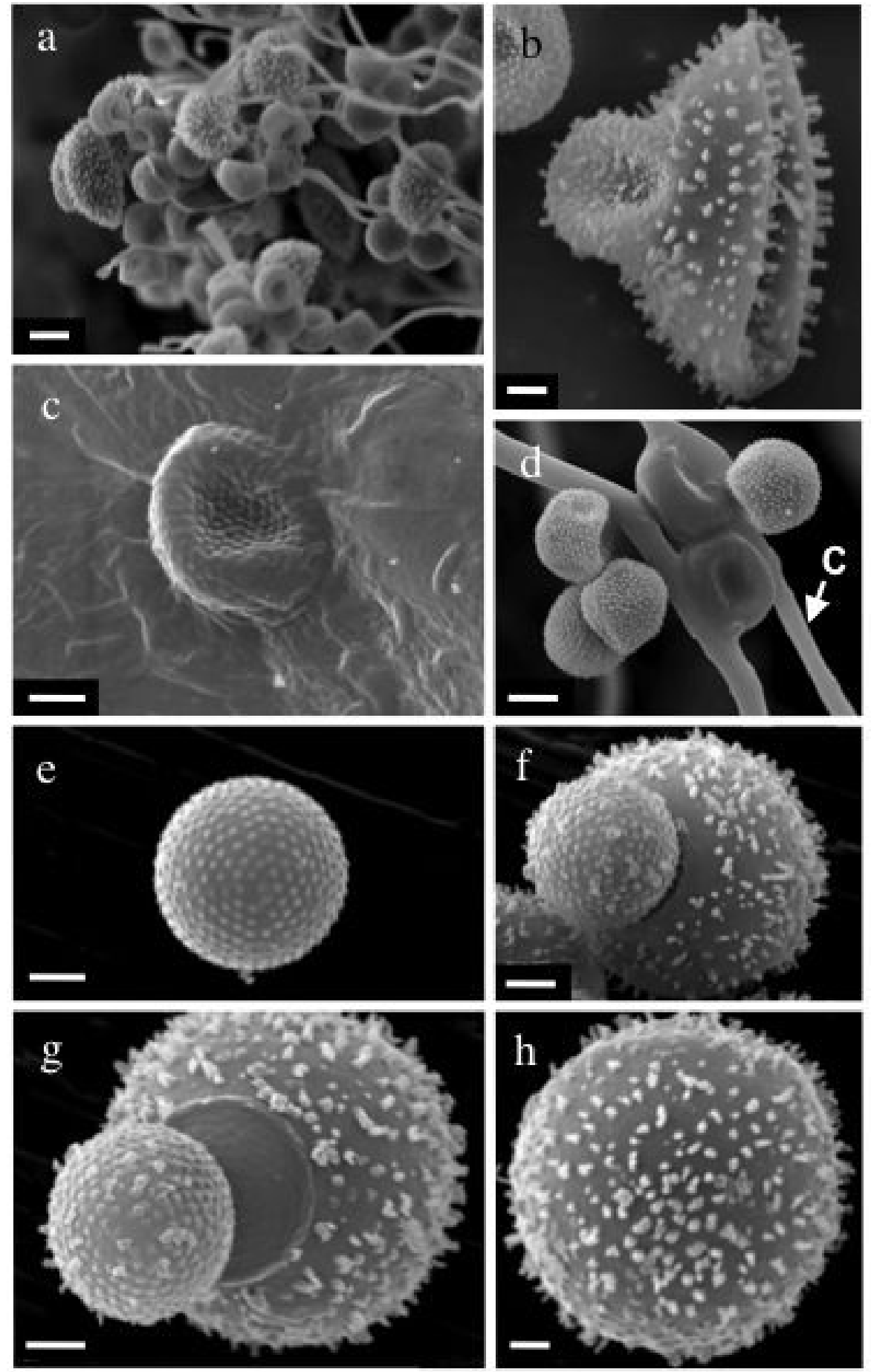

Fig. 4. Scanning electron micrographs of Lamproderma echinosporum $(T N S-M-H$ 7200). a = capillitium, spores and cyst-like bodies, $\mathrm{b}=$ spore and a cyst-like body, $\mathrm{c}=$ surface of part of a peridium and a trapped cyst-like body, $\mathrm{d}=$ part of a capillitium and four free cyst-like bodies and two trapped cyst-like bodies, $\mathrm{e}=$ cyst-like bodies, $\mathrm{f}, \mathrm{g}=$ spore and a cyst-like body, $\mathrm{h}=$ spore. Scales: $\mathrm{a}=5 \mu \mathrm{m}, \mathrm{b}, \mathrm{c}, \mathrm{e}, \mathrm{f}, \mathrm{g}=2 \mu \mathrm{m}, \mathrm{d}=3 \mu \mathrm{m}, \mathrm{h}=1 \mu \mathrm{m}$. Photos: Y. Yajima 

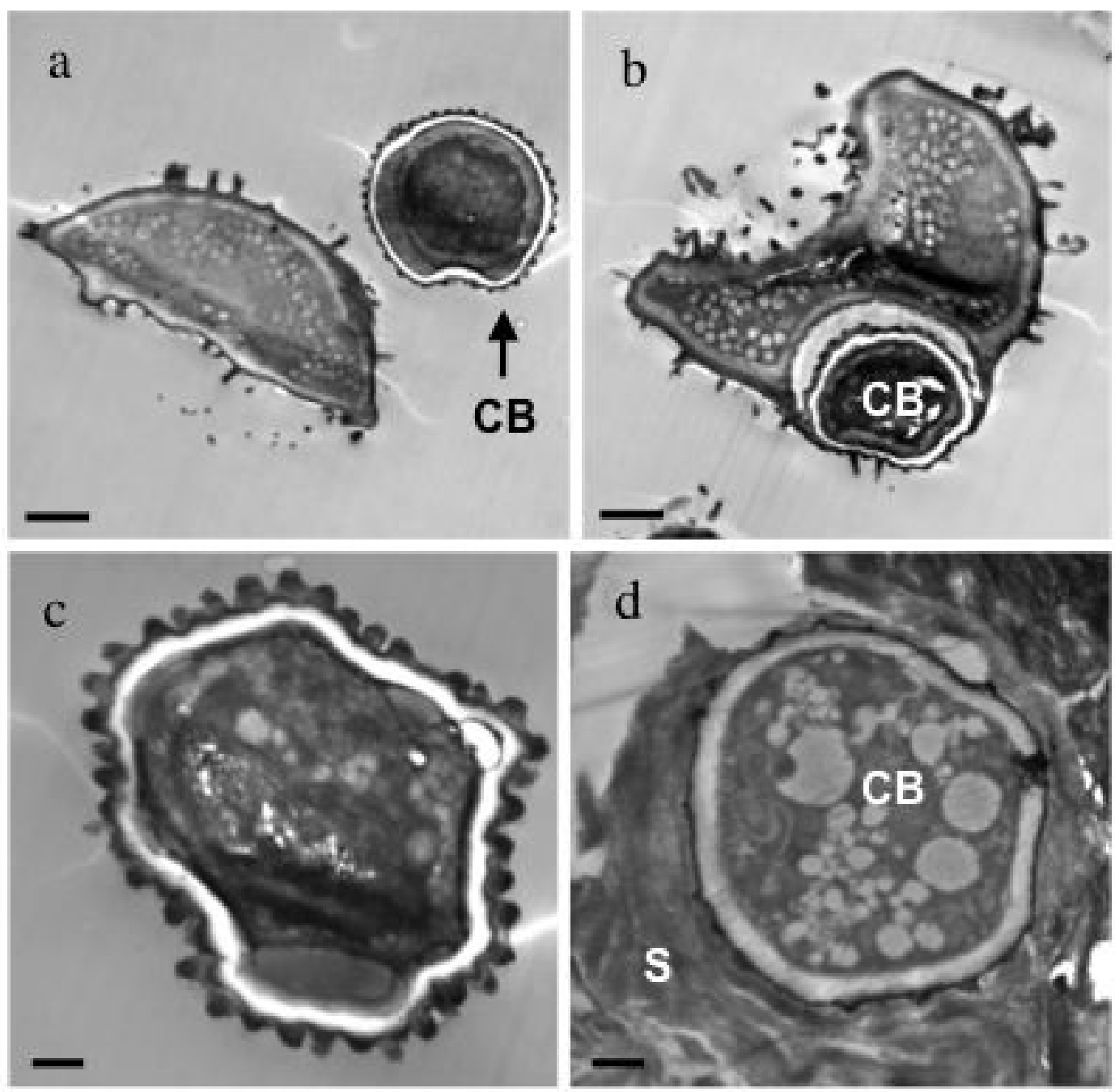

Fig. 5. Transmission electron micrographs of Lamproderma echinosporum (TNS-M-H 7200). a, b spore and a cystlike body, $\mathrm{c}=$ cyst-like body, $\mathrm{d}=$ part of horizontal section of stalk with a cyst-like body. Scales: $\mathrm{a}, \mathrm{b}=2 \mu \mathrm{m}, \mathrm{c}=0.5$ $\mu \mathrm{m}, \mathrm{d}=1 \mu \mathrm{m}$. Photos: Y. Yajima

cyst-like bodies, 5-6 $\mu \mathrm{m}$ in diam, were also observed in the sporothecae (Figs. 3e, h; Fig. 4a). This free cyst-like body was a densely uniform warted sphere under SEM (Fig. 4e) and was associated with a myxomycete spore (Figs. 3i-k; Figs. 4b, f, g). Under TEM, the cyst-like body was found associated with the outer layer of the myxomycete spore wall (Fig. 5b).

Partial 18S rRNA sequence was obtained from DNA of the cyst-like bodies in Lamproderma sp. (SAPA 100012; DDBJ accession number AB779691). Phylogenetic comparisons of the cyst-like body with previous data on the $18 \mathrm{~S}$ rDNA sequences of major eukaryotes are shown in Fig. 6. The cyst-like body is in the same clade with the Cryptomycota (including in Rozellida) which was the deepest branch of true fungi. The cyst-like body was homologous (more than 96\%) with isolates of Rozella spp. and environmental DNA (eDNA) clones of the Cryptomycota (Fig. 7), and our clone was highly homogenous (99.8\%) with the eDNA clone of lake water from the Netherlands (van Hannen et al. 1999). 


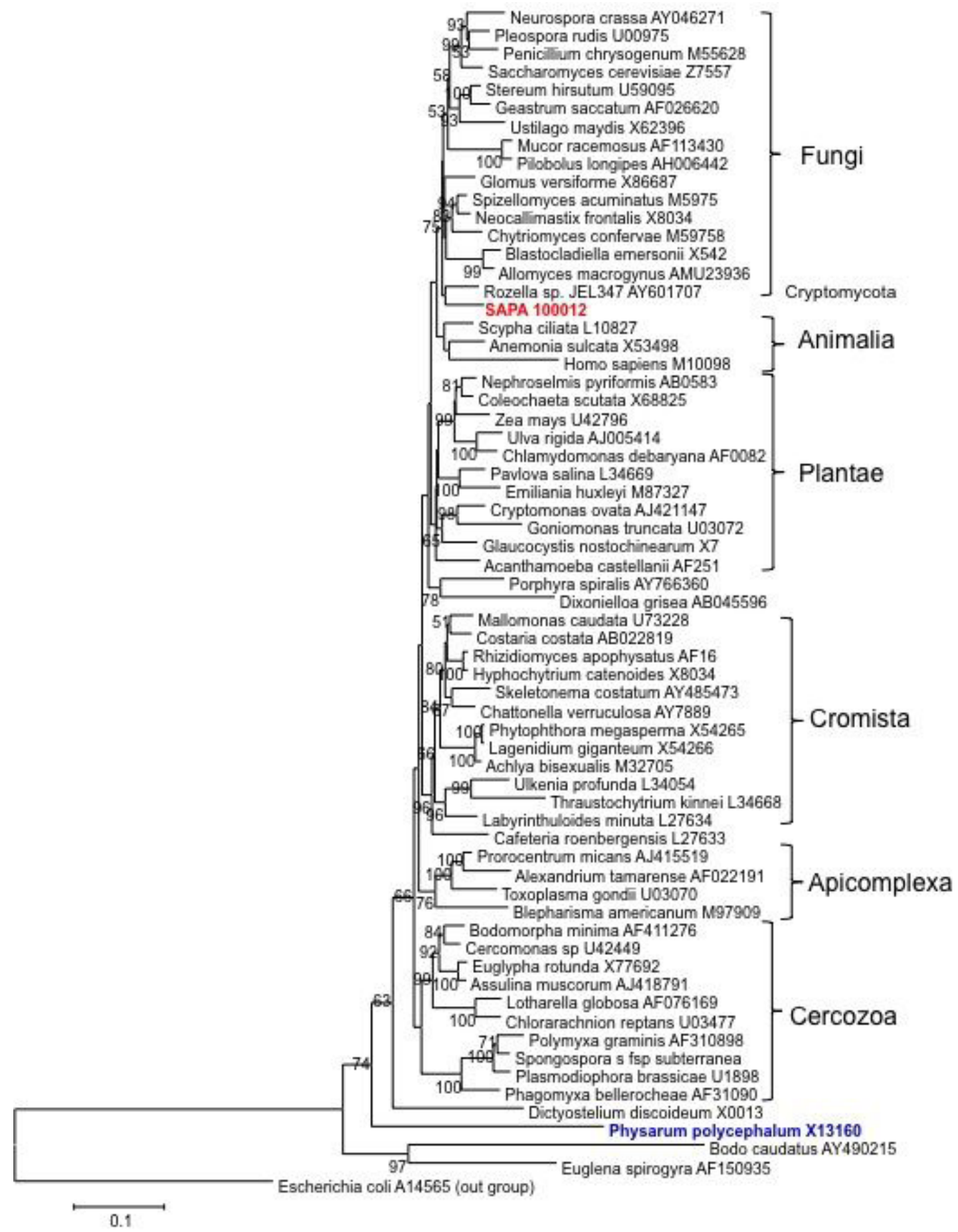

Fig. 6. Neighbor-joining (NJ) tree based on sequences of the 18S rDNA for major eukaryotes. Bootstrap percentages (from 1000 replications) greater than $50 \%$ are shown at branch points. 


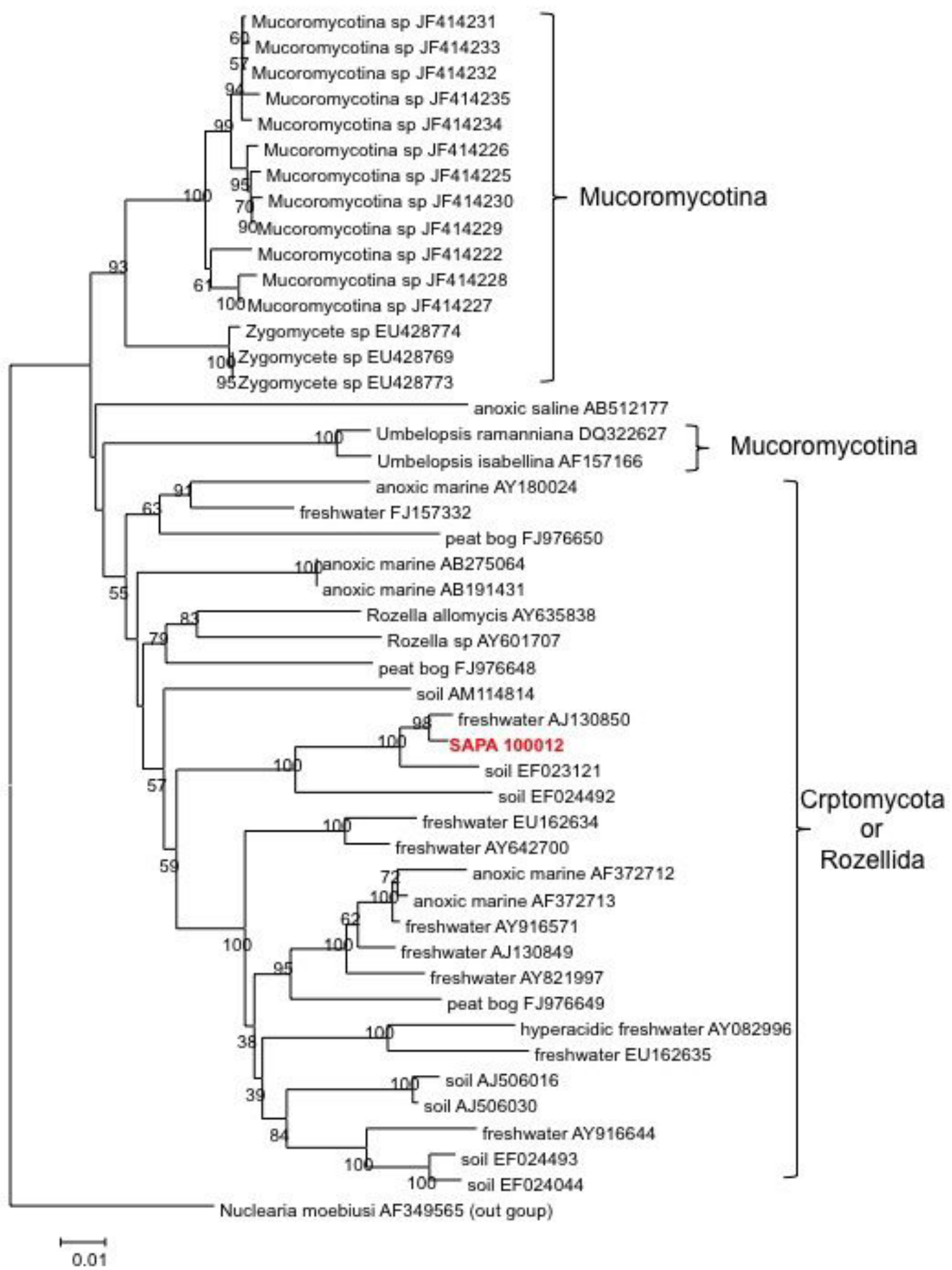

Fig. 7. Neighbor-joining (NJ) tree based on sequences of the $18 \mathrm{~S}$ rDNA for phylogenetically related clones of cyst-like body. Bootstrap percentages (from 1000 replications) greater than $30 \%$ are shown at branch points. 


\section{Discussion}

Although we could not obtain the partial sequence of the second specimen (TNS-M-H 7200), the cyst-like bodies from these two specimens appear to be of the same biological origin because of their morphological similarity. Based on the results of our phylogenetic analysis, the cyst-like bodies appear to be of fungal origin and not a myxomycete. Our results of phylogenetic analysis suggested that the cystlike bodies were a member of the Cryptomycota (Jones et al. 2011a, 2011b) including Rozellida (Lara et al. 2010) which was the deepest branch to diverge in the Kingdom Fungi. The Cryptomycota includes fungi that have unicellular, single-celled zoospores with a single microtubular flagellum and cysts without chitin/cellulose cell walls (Jones et al. 2011b). This phylum has a well supported clade from ssu rDNA sequences (Jones et al. 2011a, 2011b, Gleason et al. 2012). We did not observe any hyphae in our specimens (Figs. 1-5). These findings suggest that the cystlike bodies belong to the Cryptomycota. Rozella was the only genus in the Cryptomycota which has a genetically diverse clade, and this genus includes biotrophic fungal parasites (Chytridiomycota and Blastocladiomycota) and stramenopiles (Oomycota). Gleason et al. (2012) noted that Rozella species were specific for a single host species.

eDNA clones of cryptomycota are common in freshwater, soil and marine microbial communities (James \& Berbee 2011, Gleason et al. 2012). However, there is no record of the Cryptomycota in the cryosphere (where the biosphere is constantly or seasonally covered with snow and/ or ice). The Cryptomycota may be considered extremophiles (Gleason et al. 2012), and some eDNA clones were found from another cold environment, i.e. deep sea (Nagano et al. 2010, Nagahama et al. 2011). Fructifications of nivicolous myxomycetes occur under snow cover, therefore this also supports the suggestion that the cyst-like body represents the first record of a cryophilic fungus (Hoshino \& Matsumoto 2012) in the Cryptomycota. Nivicolous myxomycetes also are a new host for the Cryptomycota. Unfortunately we were unable to observe any specific organelles and other stages of the life cycle of the cyst-like bodies and additional fresh specimens are needed to confirm their origin.
Fructifications of myxomycetes are known as an organic substrate of various fungi. Rogerson \& Stephenson (1993) showed SEM pictures of fruiting bodies of myxomycetes colonized by Myxomyceticolous fungi. These pictures showed that the myxomycete fruiting bodies were covered by hyphae. In the present study, there were no fungal hyphae on the fruiting bodies or substratum of either myxomycete specimens, only the cyst-like bodies were observed. It is noteworthy that the cyst-like bodies were also found in the myxomycete stalks. The stalk construction of Lamproderma columbinum (Pers.) Rostaf., the type species of the genus Lamproderma, occurs at the beginning of fruiting body formation (Yajima 2011). The stalk having cyst-like bodies and no fungal hyphae on the fruiting bodies and the substratum suggested that the cyst-like bodies were already present in the plasmodium. Apparently the plasmodium moved from the place where it included the cyst-like bodies to a suitable place for fructification.

In the mature specimen (TNS-M-H 7200), the cyst-like bodies were observed in the myxomycete fruiting body, but not in the protoplasm. When the cyst-like body was found associated with the myxomycete spores, it was in the outer layer of the myxomycete spore wall. Numerous free cyst-like bodies were also observed in the sporothecae. As mentioned above, the cyst-like bodies were observed inside the stalk of specimens suggesting that they existed in the plasmodium before stalk formation at an early stage of fruiting body formation. These results indicated that myxomycetes excluded the cyst-like bodies from their protoplasm. In general, myxomycete plasmodia feed by engulfing bacteria, yeasts and small protozoans (Ing 1994, Keller et al. 2008). However, Kalyanasundaram (2004) reported that plasmodia live in close association with a bacterium, and the association, though external, confers several mutualistic benefits and enables the organism to perform certain functions which neither partner can perform by themselves. In addition, there are some reports of green algae associated with the plasmodium (Lazo 1961, Keller \& Braun 1999) and the fruiting body (McHugh 2004) of myxomycetes. These examples indicate that myxomycetes and microorganisms may have various relationships not only predator-prey, but also prey-predator, symbiosis, and parasites. 
Although the maturation of the first specimen (SAPA100012) was not completed due to lack of snow cover, the two specimens examined in this study showed that plasmodia can develop fruiting bodies in the presence of fungal cystlike bodies. Raub \& Aldrich (1982) studied the sporophore formation of Didymium iridis (Ditmar) Fr. and they concluded that the spore wall synthesis occurs in the following order: spine elaboration; outer wall synthesis; inner wall synthesis. Unfortunately we could not observe the spore wall synthesis of the second specimen, but if it occurs in the same manner, the fact that the cyst-like body was on the outer wall of the myxomycete spore indicated the cyst-like body was excluded from the protoplasm when the outer wall was synthesizing.

\begin{abstract}
Acknowledgements: We thank Dr. Tsuyoshi Hosoya (Department of Botany, National Museum of Nature and Science, Japan), who gave us permission to make electron microscope observations on TNS-M-H 7200; Dr. Takahito Kobayashi (The Hokkaido University Museum, Japan) for his help with specimen deposition; Mr. Toshiaki Ito (Research Faculty of Agriculture, Hokkaido University, Japan) for his help in using the electron microscope facilities in Hokkaido University. Mr. Ernest Emmett (Kingussie, Scotland) is thanked for checking the English language.
\end{abstract}

\section{References}

Felsenstein, J. 1985: Confidence limits on phylogenies: an approach using the bootstrap. - Evolution 39: 783 791.

Gleason, F.H., Carney, L.T., Lilje, O. \& Glockling, S.L. 2012: Ecological potentials of species of Rozella (Cryptomycota). - Fungal Ecology 5: 651-656.

Hoshino, T. \& Matsumoto, N. 2012: Cryophilic fungi to denote fungi in the cryosphere. - Fungal Biology Reviews 26: 102-105.

Ing, B. 1994: Tansley Review No. 62: The phytosociology of myxomycetes. - New Phytologist 126: 175-201.

James, T.Y. \& Berbee, M.L. 2011: No jacket required new fungal lineage defies dress code. - BioEssays 34: 94-102.

Jones, M.D.M., Forn, I., Garelha, C., Egan, M.J., Bass, D., Massana, R \& Richards, T.A. 2011a: Discovery of novel intermediate forms redefines the fungal tree of life. - Nature 474: 200-203.

Jones, M.D., Rhichards, T.A., Hawksworth, D.L. \& Bass, D. 2011b: Validation and justification of the phylum name Cryptomycota phyl. nov. - IMA Fungus 2: 173175.

Kalyanasundaram, I. 2004: A positive ecological role for tropical myxomycetes in associated with bacteria. Systematics and Geography of Plants 74: 239-242.
Keller, H.W., Aldrich, H.C. \& Brooks, T.E. 1973 : Corticolous Myxomycetes II: Notes on Minakatella longifila with ultrastructural evidence for its transfer to the Trichiaceae. - Mycologia 62: 768-778.

Keller, H.W. \& Braun, K.L. 1999: Myxomycetes of Ohio: Their Systematics, Biology and Use in Teaching. Ohio Biological Survey Bulletin New Series 13: XVI $+182 \mathrm{pp}$

Keller, H.W., Kilgore, C.M., Everhart, S.E., Carmack, G.J., Crabtree, C.D. \& Scarborough, A.R. 2008: Myxomycete plasmodia and fruiting bodies: unusual occurrences and user friendly, study techniques. Fungi 1: 24-37.

Kimura, M. 1980: A simple method for estimating evolutionary rates of base substitutions through comparative studies of nucleotide sequences. - Journal of Molecular Evolution 16: 111-120.

Lado, C. 2004: Nivicolous myxomycetes of the Iberian Peninsula: Considerations on species richness and ecological requirements. - Systematics and Geography of Plants 74: 143-157.

Lara, E., Moreira, D. \& López-García, P. 2010: The environmental clade of LKM11 and Rozella from the deepest branching clade of fungi. - Protist 161: 116121.

Lazo, W.R. 1961: Growth of green algae with myxomycete plasmodia. - The American midland naturalist 65: 381-383.

McHugh, R. 2004: Myxomycetes with solar panels. Field Mycology 5: 70.

Moreno, G., Singer, H., Sanchez, A. \& Illana, C. 2006: Diacheopsis metallica and Diacheopsis kowalskii: comparison of two distinct myxomycete species. Mycological Progress 5: 129-135.

Nagano, Y., Nagashima, T., Hatada, Y., Nunoura, T., Takami, H., Miyazaki, J., Takai, K. \& Horikoshi, K. 2010: Fungal diversity in deep-sea segments - the presence of novel fungal groups. - Fungal Ecology 3: 316-325.

Nagashima, T., Takahashi, E., Nagano, Y., Abdel-Wahab, M.A. \& Miyazaki, M. 2011: Molecular evidence that deep-branching fungi are major fungal components in deep-sea methane cold-seep sediments. - Environmental Microbiology 13: 2359-2370.

Raub, T.J. \& Aldrich H.C. 1982: Sporangia, Spherules and Microcysts. In: Aldrich, H.C. \& Daniel, J.W. (eds). Cell Biology of Physarum and Didymium. Volume II. Differentiation, Metabolism, and Methodology: 21-71. Academic Press. New York.

Rogerson, C.T. \& Stephenson, S.L. 1993: Myxomyceticolous fungi. - Mycologia 85: 456-469.

Saitou, N. \& Nei, M. 1987: The neighbor-joining method: a new method for reconstructing phylogenetic trees. Molecular Biology and Evolution 4: 406-425.

Thompson, J.D., Higgins, D.G. \& Gibson, T.J. 1994: CLUSTAL W: improving the sensitivity of progressive multiple sequence alignment through sequence weighting, position specific gap penalties and weight matrix choice. - Nucleic Acids Research 18: 7213 7218.

Ueda-Nishimura, K. \& Mikata K. 1999: A new yeast genus, Tetrapisispora gen. nov.: Tetrapisispora iriomotensis sp. nov., Tetrapisispora nanseiensis sp. nov. and Tetrapisispora arboricola sp. nov., from the Nanse 
Islands, and reclassification of Kluveromyces phaffii (van der Walt) van der Walt as Tetrapisispora phaffii comb. nov. - International Journal of Systematic Bacteriology 49: 1915-1924.

van Hannen, E.J., Mooij, W., van Agterveld, M.P., Gons, H.J. \& Laanbroek, H.J. 1999: Detritus-dependent development of the microbial community in an experimental system: qualitative analysis by denaturing gradient gel electrophoresis. - Applied and Environmental Microbiology 65: 2478-2484.

White, T. J., Bruns, T., Lee, S. \& Taylor, J. 1990: Amplification and direct sequencing of fungal ribosomal RNA genes for phylogenetics. In: Innis, M. A., Gelfand, H., Sninsky, J. S. \& White, T. J. (eds). PCR protocols: a guide to methods and application: $315-322$. Academic Press. New York.

Yajima, Y. 2011: A study of sporophore development in Lamproderma columbinum. In: Cavalcanti, LH (ed). Abstracts of $7^{\text {th }}$ International Congress on Systematics and Ecology of Myxomycetes: Universidade Federal de Pernambuco. Recife, Brazil. 